\title{
A conceptual learning model of global civic education in Indonesia
}

\author{
Sutrisno* \\ Citizenship Education, Universitas Muhammadiyah Ponorogo, Ponorogo, Indonesia \\ Sapriya, K. Komalasari \& Rahmad \\ Universitas Pendidikan Indonesia, Bandung, Indonesia
}

\begin{abstract}
This study aimed to analyze the conceptual learning model of global civic education in Indonesia. This research used mixed methods. Data collection techniques were conducted through questionnaires and interviews. The research used a stepwise qualitative-quantitative data analysis. The research was conducted on students and teachers of Pancasila and Civic Education in senior high school. The results showed that the application of the concept of global civic education in Indonesia could be actualized through the learning model of a global citizens project. A global citizens project learning model is a learning model that develops the dimensions of global citizenship of young people in critical thinking and problem solving, communication and collaboration as well as creativity and innovation in solving issues at the local, national and global levels which include the impacts of climate change, social culture, legal politic, economic, and education.
\end{abstract}

Keywords: global citizenship, learning model, Pancasila and civic education, young people

\section{INTRODUCTION}

Global problems related to local and global issues are shared problems, part of all nations throughout the world (Harshman \& Augustine, 2013). Therefore, the concept of learning at this time must contribute in shaping the skills of 21 st century citizens in an effort to prepare citizens with global perspectives who can contribute in solving problems of global and local issues.

The results of Karsten et al. (1998) also showed that there were seven global trends that needed to be addressed by each country. They were: (a) the economic gap between countries will be significantly expanded and sustainable, (b) information will increase significantly, (c) the increasing differences between those who have and lack technology, (d) conflicts between interests in developed and developing countries are increasing, (e) financing access to clean water had increased dramatically due to environmental damage and population growth, (f) illegal logging or dramatic deforestation affecting the diversity of quality of life, $(\mathrm{g})$ population growth in developing countries resulting in populations, especially children, living below the poverty line.

In line with this, the results of Murdiono's research also showed that many global problems that occurr today were certainly caused by the role of young citizens in understanding the nature of low global citizenship, especially in the learning process of civic education in schools and even colleges (Murdiono, 2014). This is also supported by the increasingly widespread dissemination of technology and information among the public. Information and communication technology (ICT) was utilized as if there was no limit to accessing it, without knowing the area and time. However, ICT could also be used as a medium for exchanging information and ideas between citizens and government (Kim et al. 2011).

${ }^{*}$ Corresponding Author 
Based on field findings and observations at the levels of senior high school, vocational high school, and madrasah aliyah, the global outlook of students was also limited to a basic understanding of the concept of problem-solving materials and global issues; it was still not a direct practice (Sutrisno, in prep.). The dimension of global citizenship students consisted of several aspects i.e., global responsibilities, global competence, and global participation which were still low both in the form of basic understanding and practice. Meanwhile, the concept of a learning model which was oriented towards improving learning skills and innovating students (critical thinking and problem solving, communication and collaboration, creative and innovative) was quite well applied. But it had not been fully developed in the form of social activities in an effort to resolve global and social issues. The concept of 21 st century learning had also not been fully developed in the learning process in the classroom by educators.

Table 1. The questionnaire results of a conceptual learning model in the global citizens project for developing learning skills and innovating learners of 21 st century students.

\begin{tabular}{lllll}
\hline No & Indicator & Results & & \\
\hline 1 & Global citizenship dimension & Global & Global & Global \\
& & responsibilities & competence & participation \\
& Research object source (90) & $40 \%$ & $35 \%$ & $40 \%$ \\
& Research outside object source (90) & $45 \%$ & $40 \%$ & $40 \%$ \\
2 & Learning and innovating skills & Critical & Communication & Innovative \\
& & thinking & collaboration & creative \\
& Research object source (90) & $50 \%$ & $50 \%$ & $45 \%$ \\
& Research outside object source (90) & $55 \%$ & $50 \%$ & $50 \%$ \\
\hline
\end{tabular}

These problems certainly must be resolved not only through legal products or government policies, but must be done early, especially in the education world. The world of education is the basis for applying the habituation of young people in building the character of national identity in encountering the developments in the 21 st century (Sutrisno, in prep.). Thus, there needs to be a reconstruction of the learning model to contribute to the resolution of issues and problems at the local, national, and global levels.

Global civic education is an educational program discourse developed by UNESCO in an effort to participate in solving various problems, issues, and conflicts globally through the learning process both in the classroom and outside the classroom (UNESCO, 2015). The application of the global civic education model for each country has differences in terms of both the approach and implementation program. There are several mappings in the implementation of global civic education in various countries. However, the concept of global civic education will be effective when each country is given a separate policy regarding the implementation of the civic education model that will be used (VanderDussen Toukan, 2018).

Thus, we need a conceptual model of the global civic education conceptual model which is ideally developed and implemented in Indonesia, especially at high schools. The concept of this learning model must be oriented to the philosophical basic values of the Indonesian people, which are based on Pancasila as the nation foundation in solving various problems, both at the local, national, and global levels (Murdiono, 2014).

\section{METHODS}

This research used a mixed methods research approach. This research used an explanatory sequential method. The data sources consisted of students and teachers of Pancasila and Civic Education at senior high school/vocational high school/madrasah aliyah levels in Ponorogo regency and outside Ponorogo regency covering various regions in Indonesia. This study used cluster random sampling 
and took five months. In Ponorogo regency, determination of research locations was based on the level of superior schools. Meanwhile, the data from outside Ponorogo regency was used as a comparison.

The first stage of this research used a quantitative method i.e., a survey about the conceptual description of the learning model of the global citizen's project. The questionnaire was used to see the extent to which the learning components of global citizenship education which include global responsibility, global competence, global participation, and learning and innovation skills have been implemented in the current learning process.

The second stage used a qualitative method. At this stage, the interview with teachers was conducted to find out the conceptual description of the implementation of global civic education learning in Pancasila and Civic Education learning in various schools. The results of this mix of methods aimed to create a conceptual model of global civic education. This conceptual final result will be developed into a prototype learning model in subsequent studies.

\section{RESULTS AND DISCUSSION}

\subsection{Concepts and theories of the global citizens project learning model as the implementation of global civic education in Indonesia}

Global civic education is a form of civic education that functions as controlling part of the education system in the 21 st century era which is full of social problems. The education system has to be prepared early on, especially in developing the character of national identity, in facing the disintegration of the nation based on the development of technology and information. Therefore, it is necessary to have a reconstruction of civic education become a global civic education that develops students' learning skills and innovation in the 21 st century. The concept of 21 st century learning is known as the global civic education learning model or global citizens project learning model. According to Reynolds, citizenship knowledge in the citizenship curriculum was usually focused on the national process with less emphasis on the international global structure. Therefore, it is necessary to have a learning model that collaborates between nationalism content and the insight of global citizens (Reynolds, 2012).

These citizen characteristics are used as the basis for the development of a global citizens project learning model that is collaborated on three dimensions of global citizens i.e. global responsibility, global competence, and global participation (Morais \& Ogden, 2011). According to Bernadette this concept was used as a media to build "connecting, creating, collaborating, and communicating across a global network," we can scaffold our students' acquisition of the habits of mind and the ways of knowing, thinking, and acting that lead them towards developing global literacy in the $21 \mathrm{st}$ century (Castek \& Dwyer, 2018).

A global project will build global insight and participation through the use of technology. Technology is the basis for developing learning skills and innovating for global citizens. One form of global civic education that can be done by teachers around the world is through global research that discusses global civic education. Projects that connect teachers around the world can be beneficial not only at a professional and pedagogical level but have proven through research, interactions with people around the world inspire personal reflection because participants learn to do global civic education (Harshman \& Augustine, 2013). The concept of global civic education must also have universal values as a form of participation in the realm of global citizens. These values can be sourced from the values of national identity that emphasize the philosophical basis of the character of global society. The characteristics of the global community do not only discuss parts of global problems but also stem from an understanding of global economic and political issues until education policies are increasingly directed towards achieving political and economic goals (Marshall, 2011).

Philosophical basic values of global civic education developed in Indonesia must be sourced from the values of God, humanity, unity, society, social justice, competition, respect for others, independence and peace (Murdiono, 2014) which are then actualized in the Global Citizens Project 
Learning Model (GCPL) process on civic education in schools especially at the senior high school level. Through the project learning model, global citizens are expected to be able to develop $21 \mathrm{st}$ century student skills, namely learning and innovating skills. One indicator of its achievement can be seen from the perspective of the value of the learning process which consists of social spiritual, knowledge, skills, and literacy competence. This competence is built based on indicators of learning and innovation skills which consist of critical thinking skills and problem solving, communication and collaboration as well as creativity and innovation (Trilling \& Fadel, 2010).

The learning process by using the global citizen project learning model can provide experience and basic knowledge for the young generation in solving problems or social conflicts in the community. This is as stated by Johnson that "Activity-driven education that improves social interaction, and thinking, reasoning, and problem solving in the classroom" (Johnson, 2015). One of the main components of the global citizens project learning model is the dimension of citizenship which identifies a conceptual model of global citizenship which includes three dimensions: social responsibility, global competence, and global community involvement (Morais \& Ogden, 2011). Social responsibility is the level of perception of interdependence with and social care for others, society, and the environment. One of global competence is to try to understand the norms and cultural expectations of others and utilize this knowledge to interact, communicate, and work effectively outside one's environment actively. Developing global competencies requires recognition of one's own limitations and ability to engage in intercultural encounters. Meanwhile, global community involvement is a demonstration of action or tendency to recognize local, national, and global community problems and respond through actions.

The Global Citizens Project Learning Model is expected to be able to provide insight for young people to take part as global nationals to jointly build a more just and civilized human civilization. The learning model of a global citizens project can be an alternative in the realm of the national education system to jointly build the skills and character of young citizens in addressing the development and use of technology and information wisely so that it will form the character of global citizens who think and have global insight but remain national character and spirit. This is because in the digital era the development of global information technology and global civic education is an important part and needs to be built as a form of global citizen participation, a sustainable future for a world that works together with mutual understanding in world citizenship (Ennals et al. 2009).

The prototype of the global citizens project learning model consists of four components which include (1) determining the topic of the project to be made which includes the impact of climate change, social culture, legal politics, economics and education, (2) creating a global citizens project design that will be made consisting of the objectives, forms and activities as well as material tools, (3) evaluation of global citizen projects consisting of the content of challenges, obstacles, and alternative policies undertaken, (4) publication of global citizens project that can be done on various social media such as Instagram, Youtube, and Facebook (Sutrisno, in prep.).

The learning model of the global citizens project has several characteristics including strengthening the values of Pancasila as the nation foundation, developing learning and innovation skills, and developing the global dimensions of students. The purpose of this learning model is to prepare young people who can participate in solving various issues at the local, national, and international scope and having a global perspective through the use of technology and information.

\subsection{Reconstruction of learning and innovation skills in the global citizens project learning model}

Twenty-first century citizen skills is a major issue in the education system in the current era to prepare young people who have critical thinking and problem solving skills, communication skills, creativity and innovation, and collaboration. Therefore, it is necessary to have the concept of learning strategies that reconstruct learning and innovation skills in the form of learning models (Trilling \& Fadel, 2010). The global citizens project learning model is a grand design between learning models that combines the material concepts of global education (global citizenship education) developed by UNESCO with the learning skills and innovating 21 st century students. Global 
civic education developed by UNESCO is the basis of the global citizens project learning model on the basis of building learning skills and innovating citizens of the 21 st century. It is reconstructed into five basic components (Eis \& Moulin-Doos, 2017).

First, the domain of learning consists of cognitive, socio-emotional, and behavioral. Second, key learning outcomes including activities in which (a) learners gain knowledge and understanding of local, national and global issues and the interrelations and interdependencies of various countries and populations, (b) learners develop skills for critical thinking and analysis, (c) students experience a shared sense of humanity, sharing values and responsibilities, based on human rights, (d) students act effectively and responsibly at the local, national, and global level for a more peaceful and sustainable world, (e) learners develop an attitude of empathy, solidarity, and respect for differences and diversity, and (f) students develop motivation and intelligence to take the necessary actions.

Third, key learning attributes consist of three main activities. They are (a) information and critical literacy which is consists of various activities that include knowing about local, national and global problems, systems and governance structures, understand the interdependence and connections of global and local problems, develop skills for critical inquiry and analysis, (b) relating socially and respecting diversity which consists of various activities which include establishing a relationship of identity and a sense of belonging, develop values and responsibilities based on human rights, develop an attitude to respect and respect difference and diversity, (c) be ethically responsible and involved in carrying out various activities that include appropriate skills, values, beliefs and attitudes, foster personal and social responsibility for a peaceful and sustainable world, and develop motivation and willingness to care for the common good.

Fourth, the topic of global civic education activities consists of nine activities that cover (a) local, national and global systems and structures, (b) issues that affect the interaction and connectivity of the community at the local, national and global level, (c) the underlying assumptions and dynamics of power, (d) different levels of identity, (e) different communities owned by people and how they are connected, (f) differences and respect for diversity, (g) actions that can be taken individually and collectively, (h) ethically responsible behavior, and (i) being involved and taking action. Fifth, education activities explain the dimensions of the age level of global civic education which is taught and can be started from the lower level, namely 5-9 years, the upper level of 9-12 years old, the lower middle level of 12-15 years and the upper secondary level 15-18+ years. Global civic education at the upper secondary level becomes an important part in building the attitudes, knowledge, and skills of young citizens of the 21st century (Eis \& Moulin-Doos, 2017).

Therefore, a mechanism for developing global citizens project learning models is needed in developing learning and innovation skills. The form of the learning development path of global civic education through the global citizens project learning model can use the learning development cycle i.e. (a) curriculum planning at this stage is carried out with analysis and planning of materials and learning objectives, (b) learning design includes analysis and planning the place of learning, the purpose of the model being developed, and the learning media used, (c) the development of learning is carried out systematically and structured in order to form the development of effective learning models, (d) learning facilities are used to implement the learning model so that it can be done sustainably, (e) the impact of learning outcomes is obtained by collecting data from the evaluation of learning (Kilfoil, 2008).

The concept of developing a global civic learning model project also originates from the elements of model development. According to Joyce (2009), there were five important elements that described a learning model, including: (a) syntax, which was a sequence of learning commonly called phases, (b) social systems namely the role of students and teachers as well as the required norms, the principle of relaxation that gave the teacher a picture of a procedure, viewed and responded to what students do, (c) support systems namely the conditions or conditions needed for the implementation of a model, such as classroom settings and instructional systems, (d) instructional impacts, and (e) accompaniment impacts. Instructional impact is a learning outcome that is achieved directly by directing students to the expected goals. The accompaniment impact is other learning outcomes produced in the teaching and learning process, as the creation of a learning atmosphere experienced directly by students without direct direction from the teacher (Joyce, 2009). 
Thus, the concept of a global citizens project learning model in developing learning and innovation skills must be oriented to the development of the 21 st century teacher education curriculum as recommended by Maphosa \& Mashau that (a) teacher education curriculum must be redesigned to assist in producing a teacher who can operate in a 21 st century environment, (b) the teaching methods used in teacher training must be based on reflection and problem solving to be instilled in the trainees of the same approach teachers should use as teachers after training, (c) a teacher-centered approach that aims at transforming students' knowledge with the concepts of learning centered, acting, and solving problems must be emphasized, (d) information technology must be fully used to improve teaching and learning inside and outside the classroom with or without the teacher's presence (Maphosa \& Mashau, 2014).

The global civic education developed by UNESCO has become the basic conceptual framework in developing learning models for global citizens' projects to shape and build learning skills and innovation of students in the 21st century. The Global Citizens Project Learning Model is reconstructed from the results of an in-depth analysis based on empirical facts that occur in the field, especially in students and teachers of Pancasila and Civic Education subjects at senior high school level. Hopefully, the Global Citizens Project Learning Model can contribute to the national education system for building young people who have 21 st century skills in the use of information and communication technology based on Pancasila values and can contribute to solving global problems and issues that occur in everyday life.

\section{CONCLUSIONS}

The learning model of the global citizens project is actualized in the learning process of Pancasila and Civic Education at the levels of senior high school, vocational school, and madrasah aliyah. The learning method used is based on student centered learning and oriented towards a scientific approach. The implementation of the global citizens project learning model is implemented in four forms of activities i.e., determining the topic, forming a global citizens project design, evaluation, and publication on social media. The learning model of the global citizens project has the characteristics of strengthening the basic values of the Pancasila as the national foundation, the development of learning skills and innovation, and the development of the global dimension of students i.e., participate to solve various issues at the local, national, and international scope and have a global perspective through the use of technology and information. This study will be the basis for future research to produce a global citizen project learning model for the development of learning and innovation skills.

\section{REFERENCES}

Castek, J. \& Dwyer, B. 2018. Think globally, act locally: Teaching climate change through digital inquiry. Reading Teacher 71(6): 755-761.

Eis, A. \& Moulin-Doos, C. 2017. Cosmopolitan citizenship education: Realistic political program or program to disillusion powerlessness? A plea for a critical power perspective within global citizenship education. Journal of Social Science Education 16(4): 49-59.

Ennals, R. et al. 2009. Global information technology and global citizenship education. AI and Society 23(1): 61-68.

Harshman, J.R. \& Augustine, T.A. 2013. Fostering global citizenship education for teachers through online research. Educational Forum 77(4): 450-463.

Johnson, K. 2015. Behavioral Education in the 21st century. Journal of Organizational Behavior Management 35(1-2): 135-150.

Joyce, B. 2009. Model-model pengajaran edisi 8. (A. Fuwaid \& A. Mirza, Trans). Yogyakarta: Pustaka Pelajar.

Karsten, S. et al. (1998). Challenges facing the 21 st century citizen: views of policy makers. In J.J Cogan \& R. Derricott (eds), Citizenship for the 21st century: An international perspective on education. London: Kogan Page Limited. 
Kilfoil, W. 2008. A model for learning development. South African Journal of Higher Education 22(5): $1019-1028$.

Kim, B.J. et al. 2011. Civic engagement and internet use in local governance. Administration \& Society, 20(9): 1-9.

Maphosa, C. \& Mashau, S.T. 2014. Examining the ideal 21st century teacher-education curriculum. International Journal of Educational Sciences 7(2): 319-327.

Marshall, H. 2011. Instrumentalism, ideals and imaginaries: Theorising the contested space of global citizenship education in schools. Globalisation, Societies and Education 9(3-4): 411-426.

Morais, D.B. \& Ogden, A.C. 2011. Initial development and validation of the global citizenship scale.

Murdiono, M. 2014. Pendidikan kewarganegaraan untuk membangun wawasan global warga negara muda. Jurnal Cakrawala Pendidikan 3(3): 349-357.

Reynolds, R. 2012. Civics and citizenship education in its global context: The complexity of global citizenship dialogues. Education Sciences 2(4): 190-192.

Sutrisno. 2019. Data Laporan Hasil Penelitian. In prep.

Sutrisno. 2019. Hasil Observasi dan Kuesioner Penelitian. In prep.

Trilling, B. \& Fadel, C. 2010. 21st century skills: Learning for life in our times. Choice Reviews Online 47(10): 47-5788-47-5788.

UNESCO. 2015. Global citizenship education: topics and learning objectives. United Nations Educational, Scientific, and Cultural Organization.

Toukan, V. E. 2018. Educating citizens of 'the global': Mapping textual constructs of UNESCO's global citizenship education 2012-2015. Education, Citizenship and Social Justice 13(1): 51-64. 